\title{
A Survey on Cut Flower Cultivar Trends and Horticultural Status of Lilies (Lilium Hybrids) in South Korea
}

\author{
Yun-Im Kang ${ }^{1,4}$, Hyang Young Joung ${ }^{1}$, Dae Hoe Goo ${ }^{1}$, \\ Youn Jung Choi ${ }^{1}$, Mok Pil Choi ${ }^{1}$, Hye Ryun An ${ }^{1}$, \\ Jae-Young $\mathrm{Ko}^{2}$, Kang-Joon Choi ${ }^{2}$, Ki Hwan $\mathrm{Lee}^{3}$, \\ and Kye Wan Hong ${ }^{3}$
}

ADDITIONAL INDEX wORDs. bulb, disease, horticultural practices, horticultural problems, Lilium hybrids, pest

SumMARY. This study investigated trends in lily (Lilium hybrids) cultivars and challenges for growing cut lily flowers using a survey of producers in the South Korean lily industry. A questionnaire requested information on various topics including the total growing area, length of farming experience, cultivars grown, factors considered when purchasing bulbs, cultivation systems, horticultural practices, disease and pest problems, and horticultural problems. The survey targeted the membership of the Korea Lily Producer Association and the number of respondents corresponded to $43 \%$ of all lily farmers in the country. Oriental-Trumpet (OT) hybrid 'Yelloween' and Oriental hybrids 'Siberia', 'Medusa', and 'Sorbonne' were mainly cultivated in South Korea. The main flower colors were yellow, white, and pink. Factors considered in choosing cultivars were the prices of bulbs and cut flowers affecting income of the farm. More than $90 \%$ of respondents used soil culture in a greenhouse to grow cut flowers. There were various horticultural practices used from planting to harvest. The main pests harming bulb and flower productivity were fungus gnat (Bradysia difformis) and bulb mite (Rhizoglyphus robini), and the most common horticultural problem was leaf scorch. Overall, the survey suggested that the stable production of lily bulb with low cost and high quality was required and practical techniques should be developed for increasing the cut lily production efficiency. In addition, the pests, diseases, and horticultural problems in the given local environmental conditions should be considered when breeding new cultivars and developing production technology.

$\mathrm{L}$ ilies as cut flowers are one of the most important ornamental plants in South Korea, whose main cultivation regions are Gangwon, Jeju, and Chungcheongnam provinces, with a total cultivation area of 215 ha and an annual value of US\$34 million in 2011 according to the Ministry of Agriculture, Food and Rural Affairs (MAFRA, 2012). Cut lilies in South Korea are ranked third in ornamental production following cut roses (Rosa $\times$ bybrida) and cut chrysanthemums (Chrysanthemum sp.), and the main types are Oriental hybrids that comprise $82 \%$ of the total cut lily production (MAFRA, 2012).

${ }^{1}$ Floriculture Research Division, National Institute of Horticultural \& Herbal Science, Suwon 441-440, Korea

${ }^{2}$ Horticulture Research Division, Gangwon Provincial Agricultural Research and Extension Services, Chunchon 200-150, Korea

${ }^{3}$ Taean Lily Experiment Station, Chungnam Agricultural Research and Extension Services, Chungnam, Taean 357-952, Korea

${ }^{4}$ Corresponding author. E-mail: yunimy@korea.kr.
Some cut lilies are consumed on the domestic market and $\approx 30 \%$ are exported to Japan. The quality and price of cut lilies are affected by their freshness, which means that South Korea, owing to its proximity, has an advantage for sales to Japan. However, the sale price of cut lilies from South Korea is lower than those from Japan in Japanese flower auctions (Seo et al., 2012). To raise the price of cut lilies, improvements in the distribution structure and quality of cut lilies are necessary, which creates a demand for research and the development of technology for all aspects of production from cultivation to distribution.

Only 8 ha are devoted to the production of lily bulbs in South Korea, therefore, most lily bulbs are imported from the Netherlands and other countries, at a total cost of about US\$7 million (MAFRA, 2012) and total number of about 24 million bulbs according to the Animal and Plant Quarantine Agency (APQA, 2012). The Netherlands, which dominates the total world bulb trade, has the largest production area with 4280 ha, and produces 2.21 billion lily bulbs (Benschop et al., 2010). The cost of purchasing lily bulbs comprises about $48 \%$ of gross margins for South $\mathrm{Ko}-$ rean lily farms according to the Rural Development Administration (RDA, 2011). Because of the financial burden of purchasing bulbs, the development of new domestic cultivars and the domestic production of lily bulbs are required.

This survey, the first of its kind in South Korea, assessed the popularity of cultivars and the characteristics of lily cultivation to use these results to develop new cultivars and cultivation techniques for South Korea's lily farms. A second objective was to determine the demands of the industry and producers and to gather specific information regarding diseases, pests, and horticultural problems in relation to their severity and differences among cultivars.

\section{Materials and methods}

The questionnaires were mailed to the members of the Korea Lily Producer Association. The questions were developed in consultation with researchers at the Lily Research Group in the RDA of South Korea. The survey questionnaire gathered the information on the lily-growing area, farmers' experience with growing lilies, cultivars, factors considered when purchasing bulbs, forms of the cultivation system, horticultural practices, disease and pest problems, and horticultural problems. Data were collected for 5 months from Mar. to July 2012. Respondents checked all applicable answers, and disease and pest problems and horticultural problems were ranked on a relative strength scale (disease and pest problems: $1=$ weakest and $5=$ severest; horticultural problems: $1=$ weakest and $6=$ severest).

\begin{tabular}{llll}
\hline $\begin{array}{l}\text { Units } \\
\begin{array}{l}\text { To convert U.S. to SI, } \\
\text { multiply by }\end{array}\end{array}$ & U.S. unit & SI unit & $\begin{array}{l}\text { To convert SI to U.S., } \\
\text { multiply by }\end{array}$ \\
\hline 0.4047 & acre $(\mathrm{s})$ & ha & 2.4711 \\
0.3048 & $\mathrm{ft}$ & $\mathrm{m}$ & 3.2808
\end{tabular}


A total of 159 usable surveys were returned from the total of 248 members, and the number of respondents corresponded to $43 \%$ of all lily farms in the country. The total growing area of respondents was 133.5 ha, comprising $62 \%$ of the total cut lily growing area of 215 ha. The average years that respondents had been cultivating lilies were 15 years (Table 1 ).

The total respondents were used for the analysis, because the number of participants per province ranged from 2 to 66. Standardized regression analyses were conducted to examine the relationship between lily cultivars and the relative strength scale of disease, pest, and horticultural problems using the canonical correlation procedure of SAS (version 9.2; SAS Institute, Cary, NC).

\section{Results and discussion}

MAIN CULTIVARS AND FACTORS CONSIDERED FOR CHOOSING CULTIVAR. Three types of lilies contribute to commercial production worldwide: the Oriental, Asiatic, and Longiflorum hybrids. According to the survey, the most common Oriental hybrid cultivars were Siberia, Medusa, and Sorbonne, all of which have white or pink petals (Table 2). These three cultivars are traded in large quantities at the Flowering Plant Joint Market in South Korea and have been exported to Japan (Kim et al., 2011; APQA, 2011). The Oriental hybrid cultivars Siberia and Sorbonne, whose bulbs were produced on 200 and 193 ha, respectively, in the Netherlands, have been in great demand worldwide (van Tuyl and Arens, 2011). Generally, high temperatures often reduce the quality of the anthocyanin color in flowers (Lai et al., 2011), but the Oriental hybrid 'Medusa' has a clear pink color in a hot summer of South Korea. The other Oriental hybrid cultivars listed by survey participants were Mero Star, Sheila, Tiber,

Table 1. Summary of lily growers' characteristic participated in the grower survey for the production of cut lilies. The questionnaires were sent to the members of the Korea Lily Producer Association and were collected. Data were collected for 5 months from Mar. to July 2012.

\begin{tabular}{lccc}
\hline $\begin{array}{l}\text { South Korean } \\
\text { Province }\end{array}$ & $\begin{array}{c}\text { Total } \\
\text { respondents (no.) }\end{array}$ & $\begin{array}{c}\text { Total growing } \\
\text { area }(\mathbf{h a})^{\mathbf{z}}\end{array}$ & $\begin{array}{c}\text { Length of farming } \\
\text { experience (yrs) }\end{array}$ \\
\hline Gyeonggi & 16 & 9.2 & 14.7 \\
Gangwon & 66 & 63.6 & 14.5 \\
Chungcheongnam & 22 & 11.9 & 19.0 \\
Chungcheongbuk & 4 & 2.1 & 16.3 \\
Jeollabuk & 13 & 12.5 & 11.6 \\
Jeollanam & 5 & 1.6 & 6.4 \\
Gyeongsangbuk & 4 & 1.4 & 5.3 \\
Busan & 2 & 0.8 & 12.5 \\
Jeju & 27 & 30.4 & 18.1 \\
Total & 159 & 133.5 & 15.0 \\
\hline
\end{tabular}

${ }^{2} 1$ ha $=2.4711$ acres.

Table 2. Main cultivars of cut lilies in South Korea based on the grower survey in 2012. The questionnaires were sent to the membership of the Korea Lily Producer Association and were collected. Respondents checked all applicable answers to the question "what cultivars and how many bulbs do you plant on your farm?" Data were collected for 5 months from Mar. to July 2012.

\begin{tabular}{|c|c|c|c|c|c|c|c|c|c|c|}
\hline \multirow{2}{*}{$\begin{array}{l}\text { South Korean } \\
\text { Province }\end{array}$} & \multirow{2}{*}{$\begin{array}{c}\text { Total } \\
\text { respondents (no.) }\end{array}$} & \multicolumn{9}{|c|}{ Lily growers by cultivar (no.) } \\
\hline & & Siberia & Sorbonne & Medusa & Casablanca & Yelloween & Augusta & Raizan & Eorayeon & Others \\
\hline Gyeonggi & 16 & 1 & 9 & 10 & 0 & 15 & 0 & 0 & 0 & 0 \\
\hline Chungcheongnam & 22 & 11 & 14 & 19 & 1 & 17 & 0 & 0 & 0 & 5 \\
\hline Chungcheongbuk & 4 & 4 & 2 & 2 & 1 & 2 & 1 & 0 & 0 & 0 \\
\hline Jeollabuk & 13 & 11 & 8 & 10 & 0 & 11 & 0 & 0 & 0 & 2 \\
\hline Busan & 2 & 2 & 1 & 1 & 0 & 2 & 0 & 0 & 0 & 2 \\
\hline Jeju & 27 & 24 & 18 & 14 & 1 & 16 & 0 & 0 & 0 & 13 \\
\hline Total & 159 & 98 & 73 & 87 & 11 & 100 & 18 & 3 & 5 & 41 \\
\hline
\end{tabular}


as the drawbacks of the distribution structure in South Korea (Seo et al., 2012). An advanced marketing strategy for the improvement of the distribution structure is needed to effectively compete on costs.

Cultivation systems and HORTICUltural PRACTICES. Most lily growers used greenhouses and 89\% of survey participants cultivated cut lilies by using soil cultures in greenhouse (Table 4). The soil culture in greenhouse systems was widely used because of the low setup cost. Only eight survey participants used soilless container culture. Although container culture is the general cultivation system in the Netherlands, container culture in South Korea was used partially with soil culture or soilless bed culture. Soilless bed culture was used by 41 survey participants. Cut lily growers have attempted to resolve disease and pest problems and soil physical and chemical problems by using hydroponics, fertigation, and soilless culture, which result in the improvement of cult flower characteristics (Chae, 2008; Tribulato and Noto, 2000). Twenty-five of survey participants in Gangwon Province cultivated cut lilies in open fields. The main cultivation areas of Gangwon Province, Inje, and Gangneung are at an elevation of about 500 to $700 \mathrm{~m}$ above sea level and the cool summer climate enables farmers to produce high-quality cut lilies. Fifty-nine of survey participants used multiple cultivation systems and most of the farmers preferred the combination of soil culture in greenhouse and openfield culture (data not shown). To generate the maximum profit, Korean lily farmers take advantage of their facility conditions, e.g., forcing cultivation in greenhouse and retarding cultivation in open field.
Table 5 shows the use of horticultural practices from planting bulbs to producing cut lilies. Soil disinfection was performed in 103 farms across the entire region using solar heat and chemicals (data not shown). Solar heat sterilization is a suitable method for the hot summers of South Korea and it improves cut flower quality (Kyung et al., 2012). Preshooting before planting was used by 69 farms. This practice allows for stable flower bud formation at forcing and retarding culture and reduces efforts because of the shorter cultivation period (Ko et al., 2012). Shading is practiced to avoid excessively high light intensity that results in leaf scorch and decrease of plant height (Cho et al., 2011). Shading was practiced by 104 farms among the survey participants and the frequency of this practice was the highest in Jeollabuk, Jeollanam, and Jeju provinces in the southern part

Table 3. Factors considered for choosing lily cultivars in South Korea based on the grower survey in 2012. The questionnaires were sent to the membership of the Korea Lily Producer Association and were collected. Respondents checked all applicable answers to the question "what factors do you consider for choosing lily cultivars?" Data were collected for 5 months from Mar. to July 2012.

\begin{tabular}{|c|c|c|c|c|c|c|}
\hline \multirow{2}{*}{$\begin{array}{l}\text { South Korean } \\
\text { Province }\end{array}$} & \multirow{2}{*}{$\begin{array}{c}\text { Total } \\
\text { respondents (no.) }\end{array}$} & \multicolumn{5}{|c|}{ Lily growers by factor considered for choosing lily cultivars (no.) } \\
\hline & & Price of bulb & Flower color & Cultivation problems & Price of cut flower & Bud number \\
\hline Gyeonggi & 16 & 10 & 2 & 0 & 5 & 3 \\
\hline Chungcheongnam & 22 & 11 & 1 & 4 & 12 & 1 \\
\hline Chungcheongbuk & 4 & 1 & 0 & 0 & 4 & 0 \\
\hline Jeollabuk & 13 & 9 & 0 & 1 & 10 & 0 \\
\hline Busan & 2 & 0 & 0 & 0 & 2 & 0 \\
\hline Jeju & 27 & 14 & 2 & 4 & 11 & 4 \\
\hline Total & 159 & 90 & 11 & 11 & 72 & 10 \\
\hline
\end{tabular}

Table 4. Cultivation systems for the production of cut lilies in South Korea based on the grower survey in 2012. The questionnaires were sent to the membership of the Korea Lily Producer Association and were collected. Respondents checked all applicable answers to the question "what cultivation systems do you use for the production of cut lilies?" Data were collected for 5 months from Mar. to July 2012.

\begin{tabular}{|c|c|c|c|c|c|}
\hline \multirow[b]{2}{*}{$\begin{array}{l}\text { South Korean } \\
\text { Province }\end{array}$} & \multirow[b]{2}{*}{$\begin{array}{c}\text { Total } \\
\text { respondents (no.) }\end{array}$} & \multicolumn{4}{|c|}{ Lily growers by cultivation systems used (no.) } \\
\hline & & $\begin{array}{l}\text { Soil culture } \\
\text { in greenhouse }\end{array}$ & $\begin{array}{c}\text { Soilless container } \\
\text { culture in greenhouse }\end{array}$ & $\begin{array}{l}\text { Soilless bed culture } \\
\text { in greenhouse }\end{array}$ & $\begin{array}{l}\text { Open-field } \\
\text { culture }\end{array}$ \\
\hline Gyeonggi & 16 & 16 & 0 & 0 & 2 \\
\hline Gangwon & 66 & 62 & 2 & 10 & 25 \\
\hline Chungcheongnam & 22 & 14 & 2 & 7 & 4 \\
\hline Chungcheongbuk & 4 & 4 & 0 & 0 & 0 \\
\hline Gyeongsangbuk & 4 & 4 & 4 & 0 & 1 \\
\hline Busan & 2 & 2 & 0 & 2 & 0 \\
\hline Jeju & 27 & 26 & 0 & 10 & 5 \\
\hline Total & 159 & 142 & 8 & 41 & 44 \\
\hline
\end{tabular}


of South Korea. Some growers operated remote-controlled sprayers and installed insect-proof nets. Hydroponics was used by farms with soilless container culture and soilless bed culture in greenhouses. To increase the use of these practices, it is necessary to educate farmers and to develop techniques appropriate for lily production.
D I S E A E S, PEST S, A N HORTICULTURAL PROBLEMS. The main disease and pest problems were botrytis blight (Botrytis sp.), fungus gnat, bulb mite, nematodes (Pratylenchus

Table 5. Horticultural practices for the production of cut lilies in South Korea based on the grower survey in 2012 . The questionnaires were sent to the membership of the Korea Lily Producer Association and were collected. Respondents checked all applicable answers to the question "what horticultural practices do you use for the production of cut lilies?" Data were collected for 5 months from Mar. to July 2012.

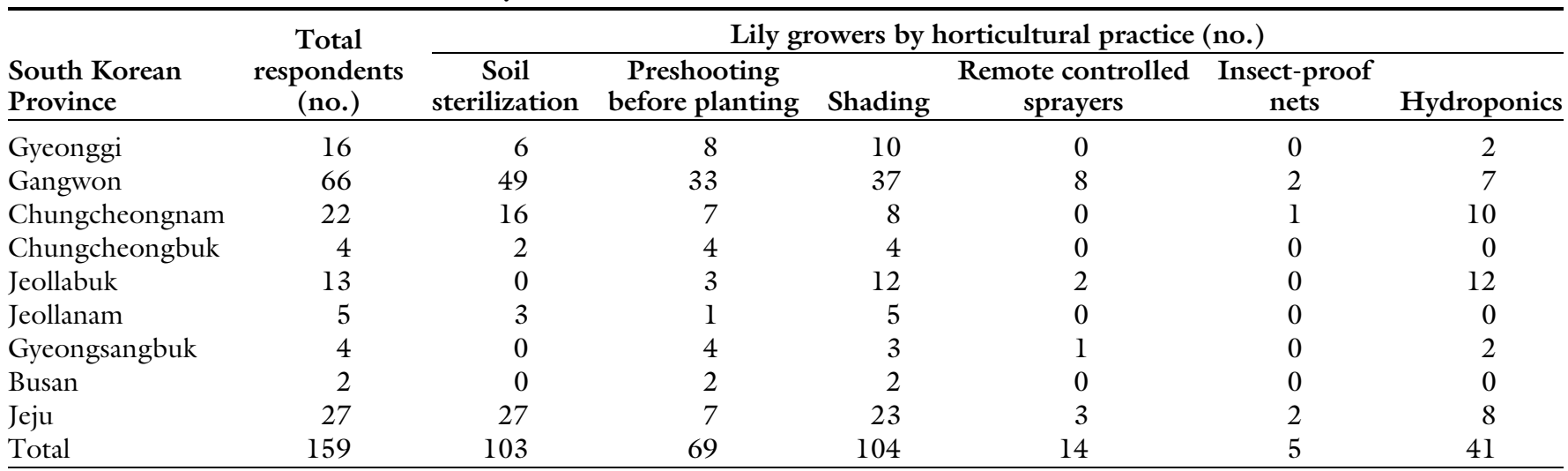

Table 6. Disease and pest problems in the production of cut lilies in South Korea based on the grower survey in 2012. The questionnaires were sent to the membership of the Korea Lily Producer Association and were collected. Respondents checked all applicable answers to the question "what disease and pest problems do you suffer on your farm?" Data were collected for 5 months from Mar. to July 2012.

\begin{tabular}{|c|c|c|c|c|c|c|}
\hline \multirow{2}{*}{$\begin{array}{l}\text { South Korean } \\
\text { Province }\end{array}$} & \multirow{2}{*}{$\begin{array}{c}\text { Total } \\
\text { respondents(no.) }\end{array}$} & \multicolumn{5}{|c|}{ Lily growers by disease and pest problem (no.) } \\
\hline & & Botrytis blight & Fungus gnat & Bulb mite & Nematodes & Viruses \\
\hline Gyeonggi & 16 & 8 & 6 & 11 & 14 & 11 \\
\hline Chungcheongnam & 22 & 11 & 10 & 16 & 17 & 15 \\
\hline Chungcheongbuk & 4 & 4 & 4 & 4 & 4 & 4 \\
\hline Jeollabuk & 13 & 7 & 9 & 11 & 10 & 10 \\
\hline Busan & 2 & 0 & 0 & 0 & 1 & 1 \\
\hline Jeju & 27 & 21 & 10 & 10 & 12 & 20 \\
\hline Total & 159 & 82 & 100 & 108 & 97 & 91 \\
\hline
\end{tabular}

Table 7. Horticultural problems in the production of cut lilies in South Korea based on the grower survey in 2012. The questionnaires were sent to the membership of the Korea Lily Producer Association and were collected. Respondents checked all applicable answers to the question "what horticultural problems do you suffer on your farm?" Data were collected for 5 months from Mar. to July 2012.

\begin{tabular}{|c|c|c|c|c|c|c|c|}
\hline \multirow[b]{2}{*}{$\begin{array}{l}\text { South Korean } \\
\text { Province }\end{array}$} & \multirow[b]{2}{*}{$\begin{array}{c}\text { Total } \\
\text { respondents (no.) }\end{array}$} & \multicolumn{6}{|c|}{ Lily growers by horticultural problem (no.) } \\
\hline & & Leaf scorch & $\begin{array}{c}\text { Flower } \\
\text { abnormality }\end{array}$ & $\begin{array}{c}\text { Flower } \\
\text { abscission }\end{array}$ & $\begin{array}{c}\text { Flower bud } \\
\text { blind }\end{array}$ & $\begin{array}{c}\text { Iron } \\
\text { deficiency }\end{array}$ & $\begin{array}{l}\text { Necrosis of } \\
\text { lower leaves }\end{array}$ \\
\hline Gyeonggi & 16 & 8 & 10 & 8 & 8 & 10 & 10 \\
\hline Gangwon & 66 & 50 & 32 & 25 & 28 & 32 & 21 \\
\hline Chungcheongnam & 22 & 18 & 10 & 12 & 6 & 8 & 13 \\
\hline Chungcheongbuk & 4 & 2 & 4 & 4 & 4 & 2 & 3 \\
\hline Gyeongsangbuk & 4 & 3 & 2 & 2 & 0 & 2 & 3 \\
\hline Busan & 2 & 0 & 0 & 0 & 0 & 2 & 0 \\
\hline Jeju & 27 & 18 & 16 & 9 & 8 & 12 & 16 \\
\hline Total & 159 & 112 & 86 & 71 & 68 & 78 & 79 \\
\hline
\end{tabular}


sp.), and viruses (lily symptomless virus, lily mottle virus, cucumber mosaic virus) in cut lily production in South Korea (Table 6). Botrytis blight causes damages to leaves, stems, and flowers at relatively high humidity and low temperatures (Hahm et al., 2007). Eighty-two survey participants responded that botrytis blight damaged cut lilies, particularly in Jeju Province. Fungus gnat larvae directly harm roots and promote pathogens such as Fusarium and Pythium (Kim et al., 2009). Hundred participants of the survey responded fungus gnats are harmful and the growers from Gangwon Province in particular considered this as a serious problem with $76 \%$ reporting it. The bulb mite was the most frequently mentioned harmful disease and pest by the respondents. The bulb mite is a serious pest worldwide and acaricides and horticultural methods have been studied and used to control the pest (Conijn et al., 1996). Ninetyseven respondents mentioned nematodes. Soil sterilization reduces the density of nematodes and promotes root development and flower weight (Kyung et al., 2012). The pests on roots and bulbs are harmful in cut flower and bulb production, therefore, studies to acquire detailed information on these pests are considered important. As growers in South Korea use bulbs once or twice before disposing of them, the number of respondents mentioning viruses is likely to be low.

Besides disease and pest problems, the main horticultural problems in lily growers in South Korea were leaf scorch, flower abnormality, flower abscission, flower bud blind, iron deficiency, and necrosis of lower leaves (Table 7). The most commonly mentioned horticultural problem was leaf scorch, followed by flower abnormality, necrosis of lower leaves, iron deficiency, flower abscission, and flower bud blind. Leaf scorch results from an imbalance between the transpiration rate and water uptake rate, which is caused by weak development of stem roots and excessive growth of

Table 8. Analysis of the relationship between lily cultivars and disease and pest problems using standardized regression coefficients. Disease and pest problems were ranked on a relative strength scale (scale of 1 to 5 where $1=$ weakest and $\mathbf{5}=$ severest). Standardized regression analyses were conducted to examine the relationship between lily cultivars and the relative strength scale of disease and pest problems.

\begin{tabular}{lccccr}
\hline $\begin{array}{l}\text { Disease and } \\
\text { pest cultivar }\end{array}$ & $\begin{array}{c}\text { Botrytis } \\
\text { blight }\end{array}$ & Fungus gnat & Bulb mite & Nematodes & Viruses \\
\hline Siberia & 0.0761 & 0.1260 & -0.0479 & $-0.1876^{*}$ & 0.0258 \\
Sorbonne & 0.0311 & -0.0320 & -0.0138 & 0.1581 & 0.0581 \\
Medusa & 0.0253 & -0.0417 & 0.1074 & $0.2103^{*}$ & 0.1067 \\
Casablanca & -0.0253 & -0.0046 & 0.0412 & -0.0123 & -0.0263 \\
Yelloween & 0.0311 & $-0.1668^{*}$ & 0.0975 & 0.0620 & 0.0173 \\
Augusta & -0.1391 & $0.3163^{* *}$ & $0.2099^{*}$ & 0.0082 & -0.1425 \\
Raizan & 0.0746 & 0.0209 & 0.0880 & -0.1167 & 0.0611 \\
Eorayeon & 0.0694 & 0.0122 & 0.0295 & 0.0119 & -0.0331 \\
\hline
\end{tabular}

$\mathrm{Ns},{ }^{*}, * *, * *$ indicate nonsignificant or significant at $P \leq 0.05,0.01$, or 0.001 , respectively. aboveground parts (Choi et al., 2004). In addition, calcium deficiency and fluoride toxicity can cause leaf scorch (Chang and Miller, 2005 ). Eighty-six survey participants responded that flower abnormalities were a problem in the production of cut lilies. Flower abscission and flower bud blind are types of flower abnormalities (Roh, 1989) that occur because of the long-term frozen storage of lily bulbs and high forcing temperatures (Lee and Roh, 2001). In particular, many growers in Chungcheongnam, Jeollabuk, and Jeju provinces, who generally use forcing cultivation, responded that flower abnormality was a severe problem. The forcing cultivation in South Korea needs to store bulbs for a long time and results in flower abnormalities because of exceedingly high temperature of summer. Iron deficiency and necrosis of lower leaves were considered to cause comparatively less damage than the other horticultural problems, and only about half of survey participants mentioned these issues. Iron deficiency is a symptom of nutrient deficiency, and the addition of iron fertilizer enables recovery (Lee et al., 2011). Necrosis of lower leaves can be caused by various factors, such as improper nutritional programs, plant spacing, and deficient light (Han, 2000). Many respondents in Jeju Province mentioned this problem, as the cut lily is mainly cultivated in winter.

RELATIONSHIP BETWEEN LILY CULTIVARS AND PROBLEMS. Standardized regression coefficients between lily cultivars and the relative strength scale of diseases, pests, and horticultural problems were computed to determine the cultivars severely damaged

Table 9. Analysis of the relationship between lily cultivars and horticultural problems using standardized regression coefficients. Horticultural problems were ranked on a relative strength scale (scale of 1 to 6 where $1=$ weakest and 6 = severest) Standardized regression analyses were conducted to examine the relationship between lily cultivars and the relative strength scale of horticultural problems.

\begin{tabular}{lcccrr}
\hline $\begin{array}{l}\text { Horticultural } \\
\text { problem cultivars }\end{array}$ & Leaf scorch & $\begin{array}{c}\text { Flower } \\
\text { abnormality }\end{array}$ & $\begin{array}{c}\text { Flower } \\
\text { abscission }\end{array}$ & $\begin{array}{c}\text { Flower bud } \\
\text { blind }\end{array}$ & $\begin{array}{c}\text { Necrosis of } \\
\text { Iron deficiency }\end{array}$ \\
\hline Siberia & 0.0671 & 0.1218 & $-0.3294^{* * *}$ & -0.0798 & -0.0246 \\
Sorbonne & 0.1372 & 0.0471 & -0.0320 & -0.0513 & 0.0397 \\
Medusa & -0.1040 & 0.0229 & 0.0610 & 0.0947 & $0.2475^{* *}$ \\
Casablanca & -0.0634 & 0.0463 & 0.0502 & 0.0427 & 0.1183 \\
Yelloween & $-0.2024^{*}$ & 0.1198 & 0.0362 & -0.1046 & -0.0318 \\
Augusta & -0.0616 & 0.0401 & -0.0043 & -0.0209 & 0.1610 \\
Raizan & -0.1294 & -0.0874 & -0.0956 & 0.1228 & 0.104 \\
Eorayeon & 0.1073 & -0.0376 & -0.0192 & 0.0852 & -0.1060 \\
\hline
\end{tabular}

Ns, ${ }^{*}, * * * * *$ indicate nonsignificant or significant at $P \leq 0.05,0.01$, or 0.001 , respectively. 
from these problems in South Korea (Tables 8 and 9). Positive standardized regression coefficients reflect severe damage and negative regression coefficients reflect minor damage and resistance to the problems. The Oriental hybrid 'Siberia' was significantly negative correlated with nematodes $(-0.1876, P \leq 0.05)$, therefore, this cultivar was more likely than the other cultivars to have nematode resistance. The Oriental hybrid 'Medusa' had poor resistance to nematodes, with a standardized regression coefficient of $0.2103(P \leq 0.05)$. The OT hybrid 'Yelloween' was less affected by fungus gnat than other cultivars $(-0.1667$, $P \leq 0.05)$. 'Augusta' hybrid easter lily (L. $\times$ formolongi) had poor resistance to fungus gnat $(0.3163, P \leq 0.001)$ and bulb mite $(0.2099, P \leq 0.05)$, which are parasitic on bulbs. Fungus gnats and bulb mites have become emerging problems in South Korea. Among horticultural problems, the occurrence of flower abscission in the Oriental hybrid 'Siberia' was low $(-0.3294, P \leq 0.001)$. The Oriental hybrid 'Medusa' was often affected by iron deficiency $(0.2475, P \leq 0.01)$. Leaf scorch was less common in the OT hybrid 'Yelloween' $(-0.2024, P \leq$ $0.05)$. These results give useful information for choosing a cultivar and developing the domestic cultivar as breeding objectives.

\section{Literature cited}

Animal and Plant Quarantine Agency. 2012. Year book of plant quarantine statistics in 2011. 1 July 2012. <http:// www.qia.go.kr/viewwebQiaCom.do?id= 32036\&type $=3 \_52$ jynb $>$.

Benschop, M., R. Kamenetsky, M. Le Nard, H. Okubo, and A. De Hertogh. 2010. The global flower bulb industry: Production, utilization, research. Hort. Rev. $36: 1-115$.

Chae, S.C. 2008. Effect of planting density, growing medium and nutrient solution strength on growth and development of lily in box culture. Flower Res. J. 16:36-43.

Chang, Y.C. and W.B. Miller. 2005. The development of upper leaf necrosis in Lilium 'Star Gazer' J. Amer. Soc. Hort. Sci. 130:759-766.

Cho, W.S., Y.G. Park, and B.R. Jeong. 2011. Effect of cultivation type and shading on the growth characteristics of Lilium oriental hybrids grown for seed bulbs in highland in summer. Flower Res. J. 19:1-7.

Choi, J.J., J.S. Lee, J.M. Choi, and E.M. Lee. 2004. Growth and flowering characteristics of lily cultivars as pot plants. J. Korean Flower Res. Soc. 12:119-126.

Conijn, C.G.M., K. Altena, and I. Lesna. 1996. Biological control of the bulb mite Rhizoglyphus robini by the predatory mite Hypoaspis aculeifer on lilies: Implementation in practice. Acta Hort. 430:619-624.

Hahm, S.S., K.H. Lee, J.W. Lee, H.D. Lee, and S.H. Yu. 2007. Control and incidence of leaf blight on lily with different cultural systems. Res. Plant Dis. 13: 152-156.

Han, S.S. 2000. Growth regulators reduce leaf yellowing in easter lily caused by close spacing and root rot. HortScience 35:657-660.

Kim, H.H., H.J. Jeon, C.Y. Yang, T.J. Kang, and Y.K. Han. 2009. Transmission of Fusarium oxysporum by the fungus gnat, Bradysia difformis (Diptera: Sciaridae). Res. Plant Dis. 15:262-265.

Kim, J.Y., J.W. Hong, K.W. Han, E.J. Jang, and C.H. Pak. 2011. Effects of bulb circumference and cultivar on the cut flower quality in lily. Flower Res. J. 19: 197-201.

Ko, J.Y., K.J. Choi, D.K. Hong, and H.K. Rhee. 2012. Effect of pre-shooting duration on cut flower quality of Lilium oriental hybrid depending on planting time. Flower Res. J. 20:1-6.

Kyung, K.C., S.S. Hahm, K.H. Lee, C.G. Lee, W.S. Kim, K.W. Hong, D.H. Yi, J.W. Lee, and J.J. Choi. 2012. Reduction of nematode density in lily cultivation soil by disinfection and input of microorganisms in summer season. Korean J. Hort. Sci. Technol. 30:189. (Abstr.).

Lai, Y.S., M. Yamagishi, and T. Suzuki. 2011. Elevated temperature inhibits anthocyanin biosynthesis in the tepals of an oriental hybrid lily via the suppression of LhMYB12 transcription. Sci. Hort. 132: 59-65.

Lee, J.W., K.W. Hong, J.J. Choi, H.D. Lee, and J.Y. Ko. 2011. Effect of drenching ferrous sulphate for overcoming iron deficiency during media cultivation in lily. Korean J. Hort. Sci. Technol. 29:162. (Abstr.).

Lee, J.S. and M.S. Roh. 2001. Influence of frozen storage duration and forcing temperature on flowering of oriental hybrid lilies. HortScience 36:1053-1056.

Ministry of Agriculture, Food and Rural Affairs. 2012. Statistics for floricultural industry in 2011. 31 July 2012. <http:// www.mafra.go.kr/list.jsp? id=28564\& pageNo=1\&NOW_YEAR $=2012 \&$ group_ 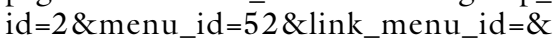 division $=$ B\&board_kind $=C \&$ board_skin_ 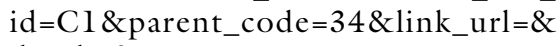 depth $=2>$.

Roh, M.S. 1989. Bud abnormalities during year-round forcing of Asiatic hybrid lilies. Acta Hort. 266:147-154.

Rural Development Administration. 2011. Regional agriculture income data for 2010. 1 Sept. 2011. <http://amis.rda. go.kr/soduk/2011_local_data.pdf>.

Seo, J.K., J.H. Kim, C.Y. Song, and W.H. Choi. 2012. Exporting strategy of cut lily in Korea. Flower Res. J. 20:268-274.

Tribulato, A. and G. Noto. 2000. Forcing oriental and asiatic lilies in soilless culture. Acta Hort. 559:639-645.

van Tuyl, J.M. and P. Arens. 2011. Lilium: Breeding history of the modern cultivar assortment. Acta Hort. 900:223 230.

Xuan, Y. and J.H. Kim. 2009. Breeding of Lilium $\times$ formolonga $\mathrm{F}_{1}$ hybrid 'Eorayeon 1ho' for cut flower. Flower Res. J. 17: 324-327. 